\title{
Lichens and allied fungi of old parks of three museum-reserves in Moscow Region (Russia)
}

\author{
Evgeniya E. Muchnik ${ }^{1} \&$ Diana A. Cherepenina ${ }^{1,2,3}$ \\ ${ }^{1}$ Laboratory of Broadleaved Forests Ecology, Institute of Forest Science RAS, Sovetskaya St. 21, 143030 Uspenskoye, \\ Odintsovo District, Moscow Region, Russia \\ E-mail: emuchnik@outlook.com \\ ${ }^{2}$ Tsitsin Main Botanical Garden RAS, Botanicheskaya St. 4, 127276 Moscow, Russia \\ E-mail: diana0075@mail.ru \\ ${ }^{3}$ Department of Ecology, Peoples' Friendship University of Russia, Podolskoe shosse 8/5, 113093 Moscow, Russia
}

\begin{abstract}
We present the results of lichenological research in the parks of the museum-reserve Abramtsevo, the museumreserve of A. S. Pushkin and the museum-estate Ostafyevo - Russian Parnassus, for which no previous data were available. The checklist of lichen biota contains 103 species including 98 lichens, a lichenicolous fungus and 4 non-lichenized fungi. 55 species were found in the park of the museum-reserve Abramtsevo, 58 species in the museum-reserve of A. S. Pushkin (estates Vyazemy - 51 and Zakharovo - 29) and 69 species in the museum-estate Ostafyevo - Russian Parnassus. Lichenochora obscuroides (Ostafyevo) is new for Central Russia. Cladonia macilenta, Evernia prunastri and Usnea hirta (Ostafyevo) are listed in the Red Data Book of Moscow. Parmelina tiliacea (Abramtsevo, Vyazemy), Ramalina farinacea, Usnea dasopoga and $U$. subfloridana (Abramtsevo) are listed in the Red Data Book of the Moscow Oblast. Chaenotheca chrysocephala, Melanelixia subargentifera, Parmelina tiliacea, Physconia perisidiosa and Ramalina europaea (Ostafyevo) are proposed for inclusion in the next edition of the Red Data Book of Moscow.
\end{abstract}

Keywords: lichen biota, lichenicolous fungi, biodiversity, indicator species, Red Data Book, park communities, Central Russia

\section{INTRODUCTION}

Old parks in urbanized landscapes are shelters for biodiversity including lichens (Likhacheva, 2010; Liira et al., 2020). In Russia, the parks of the museum-reserves (museum-estates) are usually natural areas having historical and cultural heritage value, which are specially protected at the federal level (Muchnik, 2015). Therefore, they can be considered as promising territories for environmental monitoring in anthropogenically transformed regions. Lichens of the parks of the museum-reserves have repeatedly been objects of research in Central Russia (Malysheva, 1999; Gudovicheva, 2001; Muchnik, 2014; Muchnik, 2015; Gagarina et al., 2020; etc.). However, lichens of the parks of the museums-reserves in the Moscow Region (Moscow and the Moscow Oblast) are poorly studied. In total, there are 14 museums-reserves in the Moscow Region, which include 20 manor parks. Prior to our research, only fragmentary information was available about the lichens of three parks in the city of Moscow, namely the parks Tsaritsyno (Biazrov, 2009), Kolomenskoye and Lefortovo (Pchelkin, 1998; Pchelkin $\&$ Pchelkina, 2015). Thirteen species of lichens were found in Tsaritsyno, of which seven species are known by the historical data from the early 20 th century. Forty-five species are known from Kolomenskoye, two species of them are listed in the Red Data Book of Moscow: Graphis scripta (L.) Ach. and Protoparmeliopsis muralis (Schreb.) M. Choisy; two further species are reported from Lefortovo.

Biodiversity exploration in the parks of the museum-reserve (MR) Abramtsevo, the MR of A. S. Pushkin and the museum-estate (ME) Ostafyevo - Russian Parnassus has been started very recently. The published accounts display taxonomic, ecological and sozological analyses, and state assessment of lichen biota (Muchnik et al., 2018; Muchnik \& Cherepenina, 2018; Cherepenina \& Muchnik, 2019). This paper presents a full lichen checklist of all surveyed parks and a comparative analysis of species richness and lichen diversity.

\section{MATERIAL AND METHODS}

The lichen biota of the parks of the MR Abramtsevo, the MR of A. S. Pushkin (estates Vyazemy and Zakharovo) and the ME Ostafyevo - Russian 
Parnassus (Fig. 1) was studied in 2016-2018. The surveyed parks are located in the subzone of mixed coniferous-broadleaved forests of the East European Plain in the moderately continental climate zone (Kolosova \& Churilova, 2004). Acer platanoides L., Betula sp., Picea abies (L.) H. Karst., Pinus sylvestris L., Populus tremula L., Quercus robur L. and Tilia cordata Mill. are typical tree species in coniferous-broadleaved forests and prevail in park plantations. All parks have total area about $32-50$ ha and they all originate from the 18 th century. The age of some trees exceeds 200 years. According to Kolosova \& Churilova (2004), the ME Ostafyevo is located in an area with high degree of anthropogenic impact, and the MRs of A. S. Pushkin and Abramtsevo are situated in areas with moderate degree of anthropogenic impact. However, the MR Abramtsevo is located near a village, while the MR of A. S. Pushkin is situated inside a small town with a greater anthropogenic load.

27 sample plots were examined across all three museum-reserves: plots 1-5 in the MR Abramtsevo, 6-13 in the estate Vyazemy and 14-16 in the estate Zakharovo within the MR of A. S. Pushkin, and 17-27 in the ME Ostafyevo; additional data about the studied localities (geographical coordinates, areas, tree species) are presented in Appendix 1.

Morphology and anatomy of collected vouchers were studied by routine microscopic and laboratory techniques. Some sterile specimens were determined by thin layer chromatography (TLC) (Orange et al., 2001). 1096 identified specimens are deposited in the herbarium of Tsitsin Main Botanical Garden RAS (MHA). The nomenclature follows Nordin et al. (2011). Indicator species of old-growth forest and park communities were selected following Himelbrant \& Kuznetsova (2009) and Muchnik (2015a). Protected species are listed following the Red Data Book of Moscow (2011) and Red Data Book of the Moscow Oblast (2018). The Sørensen Index (Sørensen, 1948) was calculated to determine the similarity of lichen biota. The specificity of lichen biota of the surveyed parks $(\mathrm{K})$ was calculated by the formula: $\mathrm{K}=(\mathrm{a} / \mathrm{b}) \times 100$, where $\mathrm{a}-$ number of species found only in one of the surveyed parks, $b$ - total number of species found in all surveyed parks. Menhinik Index was calculated to determine the relative indicator of the species richness of lichen biota. Shannon Index of Diversity, which also takes into account the structural aspect, was calculated for a generalized assessment of diversity. Both indices are quite widely used in biodiversity studies as they allow comparisons of samples with different sizes (Magguran, 2004).

\section{RESULTS AND DISCUSSION}

The study revealed 103 species: 98 lichens, a lichenicolous fungus and 4 non-lichenized fungi (Table 1). 55 species were found in the park of the MR Abramtsevo, 58 species in the MR of A. S. Pushkin (in estates Vyazemy -51

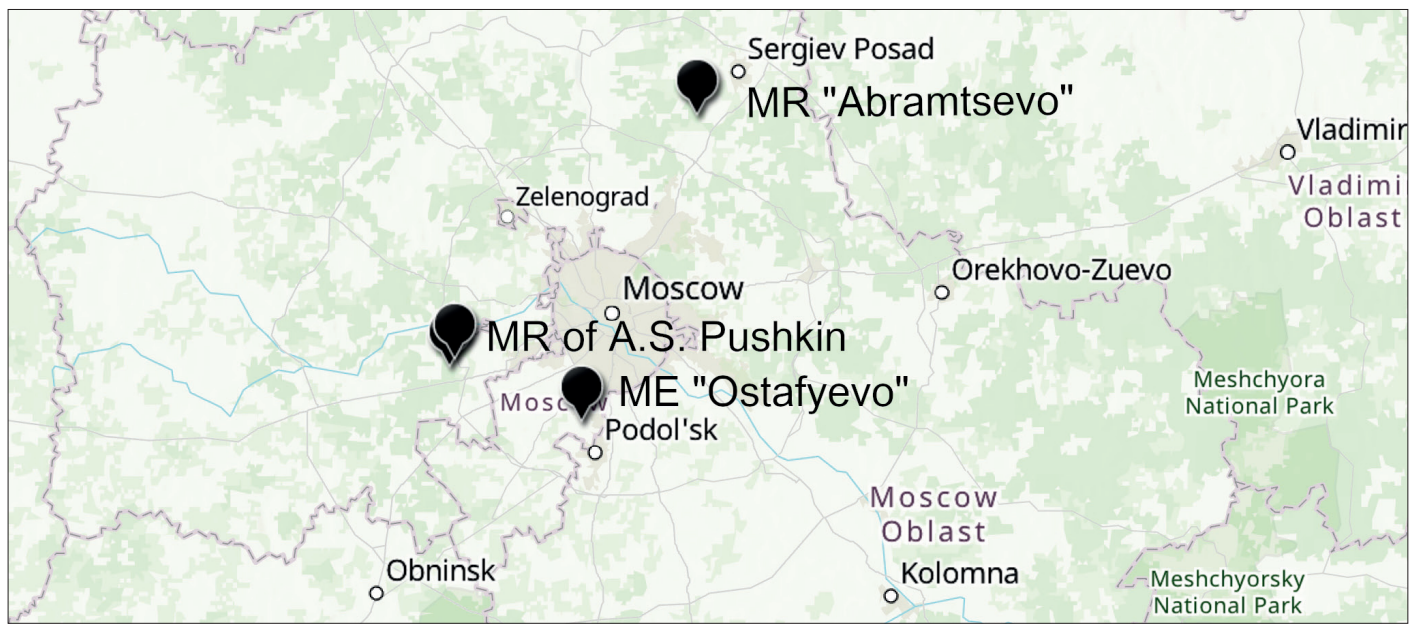

Fig. 1. The locations of the studied parks of the museum-reserves in the Moscow Region. 
and Zakharovo - 29) and 69 species in the ME Ostafyevo - Russian Parnassus. The lichen diversity in the surveyed parks is higher than in the manor parks of the neighboring Smolensk Region. Studies of that Region reveal the highest diversity of 41 species in the Natural Monument Dugino (36 ha) while the other manors had 7-39 species and lacked protection value (Gagarina et al., 2020). Apparently, the federal protection of the museums-reserve's parks in Moscow region has a positive effect on the lichen biodiversity.

\section{Comments on the species}

The lichenicolous fungus Lichenochora obscuroides is new for Central Russia. Its known distribution in European Russia: Kaliningrad, Leningrad, Samara Regions and Republic of Bashkortostan (Tsurykau \& Korchikov, 2017). However, it is likely to be widespread but undercollected as the host, Phaeophyscia orbicularis, is very common within the study area.

Candelaria concolor was previously reported as Candelaria pacifica M. Westb. \& Arup. (Muchnik $\&$ Cherepenina, 2018), but later re-identified by A. Tsurykau. Ramalina europaea from MR Abramtsevo (point 2) was previously reported as Ramalina pollinaria (Westr.) Ach. (Muchnik et al., 2018), but was later re-identified by A. Tsurykau, as Ramalina europaea has recently been described by a combination of morphological and genetic characteristics (Gasparyan et al., 2017). Xanthomendoza fallax was previously reported as Xanthomendoza huculica (S.Y. Kondr.) Diederich (Cherepenina \& Muchnik, 2019), which is currently considered as a synonym of X. fallax (Lindblom et al, 2019).

\section{Analysis of the lichen biota}

Candelariella efflorescens, Hypogymnia physodes, Lecania fuscella, Lecanora symmicta, Parmelia sulcata, Phaeophyscia orbicularis, Physcia adscendens, P. aipolia, Physconia enteroxantha and Xanthoria parietina form the core of lichen biota in the studied parks. In our definition, the "core of lichen biota" is identical to the concept of "core of bryoflora" (Maslovsky, 1990) and is considered from the point of view of the species occurrence. The core species are most widespread, have a stable position in the community and are able to withstand significant environmental fluctuations.
Cladonia macilenta, Evernia prunastriand Usnea hirta (Ostafyevo) are listed in the Red Data Book of Moscow (2011). Parmelina tiliacea (Abramtsevo, Vyazemy), Ramalina farinacea, Usnea dasopoga and U. subfloridana (Abramtsevo) are listed in the Red Data Book of the Moscow Oblast (2018). Also, Hypogymnia tubulosa (Abramtsevo, Zakharovo) is listed in the Appendix of the Red Data Book of the Moscow Oblast as a rare and vulnerable species that needs constant monitoring. Other rare and interesting records for park communities include Arthonia punctiformis, Arthopyrenia analepta, Biatora helvola, Chaenotheca chrysocephala (Ostafyevo), C. trichialis (Abramtsevo, Vyazemy, Ostafyevo), Lecidea erythrophaea (Vyazemy), Parmeliopsis ambigua (Abramtsevo, Zakharovo), Pycnora sorophora (Vyazemy). These species have forest ecology and are more characteristic for zonal forest communities.

Furthermore, Alyxoria varia (Ostafyevo), Caloplaca obscurella (Zakharovo), Catinaria atropurpurea (Vyazemy), Melanelixia subargentifera (Ostafyevo), Parmelina tiliacea (Vyazemy, Ostafyevo) and Physconia perisidiosa (Abramtsevo, Ostafyevo) are indicators of biologically valuable forest and park landscapes in the subzone of mixed coniferous-broadleaved forests (Muchnik, 2015a). Within the subzone, these species inhabit only old-growth forest and park communities, hence we consider them as indicators of old-aged forest and park communities.

According to the specificity values (Table 2), each park includes a notable proportion of species not found in the other parks, contributing differently to the lichen biota of the region. As a result, all studied park communities are valuable biotopes for lichens and should be conserved as habitats of rare lichen species, including lichens typical for forest ecology, indicator species and redlisted species. However, the lichen biota of park of the ME Ostafyevo has the highest number of unique species due to higher number of preserved old-growth trees (especially Ulmus glabra Mill.), creating additional micro-habitats for lichens.

The parks of the MR of A. S. Pushkin and the ME Ostafyevo are most similar considering lichen biota, according to Sørensen Index values (Table 3). These parks have greater similarity of planted 
Table 1. List of recorded species in the parks of three museum-reserves in Moscow region. The following symbols are used: \# - lichenicolous fungi; + - allied non-lichenized fungi; * indicator species of old-aged forest and park communities; ! - the species is in the Red Data Book of Moscow; !! - the species is in the Red Data Book of the Moscow Oblast; new species for Central Russia is in bold.

Taxon
*Alyxoria varia (Pers.) Ertz \&Tehler
Amandinea punctata (Hoffm.) Cop-
pins \& Scheid.
Anisomeridium polypori (Ellis \&
Everh.) M. E. Barr
Arthonia punctiformis Ach.
Arthopyrenia analepta (Ach.) A.
Massal
Athallia holocarpa (Hoffm.) Arup
et al.
Athallia pyracea (Ach.) Arup et al.

Bacidina chloroticula (Nyl.) Vězda \& Poelt

Biatora globulosa (Flörke) Fr.

Biatora helvola Körb. ex Hellb.

Buellia griseovirens (Turner \& Borrer ex Sm.) Almb.

Caloplaca cerina (Hedw.) Th. Fr.

${ }^{*}$ Caloplaca obscurella (J. Lahm ex Körb.) Th. Fr.

Candelaria concolor (Dicks.) Stein

Candelariella efflorescens R. C. Harris 2 \& W. R. Buck

Candelariella vitellina (Hoffm.) Müll. Arg.

Catillaria nigroclavata (Nyl.) Schuler

* Catinaria atropurpurea (Schaer.) Vězda \& Poelt

Chaenotheca chrysocephala (Turner ex Ach.) Th. Fr.

Chaenotheca ferruginea (Turner ex 2, 4, 5 Sm.) Mig.

Chaenotheca trichialis (Ach.) Th. Fr. 2

Cladonia chlorophaea (Flörke ex Som- 1, 2, 4 merf.) Spreng.

Cladonia coniocraea (Flörke) Spreng. 1, 2, 4, 5

Cladonia digitata (L.) Hoffm.

2, 4
Study plots within the museum-reserves Substrata and notes

Abramtsevo A. S. Pushkin Ostafyevo

19 bark of old Ulmus sp.

6-9, 11 18-20, 23, bark of old Betula sp., Larix sibirica Ledeb., 25 Malus sp., old Pinus sylvestris, old Quercus robur, Tilia cordata

10

bark of Acer platanoides

25 bark of old Betula sp.

23 bark of old Acer platanoides

$17 \quad$ treated wood

7, 9, 13, 14 17, 27 bark of Acer platanoides, old Betula sp., Fraxinus sp., Populus sp., Populus tremula, Salix sp., branches of deciduous trees

rotted wood; det. G. P. Urbanavichus

19, 24 bark of Quercus robur, Tilia cordata

17 branch of Betula sp.

$8 \quad$ 18, 25 bark of Betula sp., old Pinus sylvestris, rotted wood; TLC: atranorin, norstictic acid

7, 9, $15 \quad 23,27 \quad$ bark of Acer platanoides, Malus sp., Populus tremula, old Salix sp.

15 on bark of old Pyrus sp.; det. A. G. Paukov

$12 \quad$ bark of old Larix sibirica

6, 7, $\quad 17-27 \quad$ bark of deciduous trees, bark and branch

9-15 of Pinus sylvestris, treated wood

18, 20, 23 bark of Malus sp., Syringa sp., branches of Tilia cordata

9, $14 \quad$ 17, 18, 25, bark of old Betula sp., old Salix sp., Tilia

$27 \quad$ cordata, branches of Pinus sylvestris, Tilia cordata, treated wood

8

rotted wood

19 bark of old Ulmus sp.

18, 19, 25 bark of old Picea abies, Pinus sylvestris, old Tilia cordata

$9 \quad 18,19$ bark of old Picea abies, old Tilia cordata

14-16 17, 19, 20, bark of Betula sp., Quercus robur, Tilia $22,24,25$, cordata 27

7, 10, 12, 14, $17-20$, bark of Betula sp., old Quercus robur, Tilia $16 \quad 22-25,27$ cordata, rotted wood

19, 22 bark of Betula sp., Tilia cordata 
Table 1. (continued)

\begin{tabular}{|c|c|c|c|c|}
\hline \multirow[t]{2}{*}{ Taxon } & \multicolumn{3}{|c|}{ Study plots within the museum-reserves } & \multirow[t]{2}{*}{ Substrata and notes } \\
\hline & Abramtsevo & A. S. Pushkin & Ostafyevo & \\
\hline Cladonia fimbriata (L.) Fr. & 1,4 & $7,12,16$ & $\begin{array}{l}17-20,22, \\
24-27\end{array}$ & $\begin{array}{l}\text { bark of Betula sp., old Pinus sylvestris, old } \\
\text { Quercus robur, old Tilia cordata, rotted } \\
\text { wood }\end{array}$ \\
\hline ! Cladonia macilenta Hoffm. & 4 & & 19,25 & bark of old Betula sp., old Quercus robur \\
\hline Evernia mesomorpha $\mathrm{Nyl}$. & 5 & & & bark of Betula sp. \\
\hline ! Evernia prunastri (L.) Ach. & 1,4 & & 18,20 & bark of Betula sp., Tilia cordata \\
\hline $\begin{array}{l}\text { Fuscidea arboricola Coppins \& } \\
\text { Tønsberg }\end{array}$ & 2 & & & bark of Quercus robur, Tilia cordata \\
\hline Fuscidea pusilla Tønsberg & & & 27 & $\begin{array}{l}\text { bark of old Betula sp;; } \\
\text { TLC: divaricatic acid }\end{array}$ \\
\hline $\begin{array}{l}\text { Hypocenomyce scalaris (Ach.) M. } \\
\text { Choisy }\end{array}$ & $1,2,4$ & & 24,25 & $\begin{array}{l}\text { bark of Betula sp., old Picea abies, old Pinus } \\
\text { sylvestris, old Tilia cordata, rotted wood }\end{array}$ \\
\hline Hypogymnia physodes (L.) Nyl. & $1-5$ & $8,11,14-16$ & $\begin{array}{l}17-20,24 \\
25,27\end{array}$ & $\begin{array}{l}\text { bark and branches of deciduous and co- } \\
\text { niferous trees }\end{array}$ \\
\hline Hypogymnia tubulosa (Schaer.) Hav. & 1,4 & 15 & & on bark of Betula sp., old Pyrus sp. \\
\hline $\begin{array}{l}\text { + Julella fallaciosa (Stizenb. ex Arnold) } \\
\text { R. C. Harris }\end{array}$ & & & $\begin{array}{l}17-19,24 \\
25\end{array}$ & bark of Betula sp. \\
\hline Lecania cyrtella (Ach.) Th. Fr. & 1,4 & 7,9 & 21,27 & $\begin{array}{l}\text { bark of Fraxinus sp., Populus tremula, Salix } \\
\text { sp., Tilia cordata }\end{array}$ \\
\hline Lecania cyrtellina (Nyl.) Sandst. & 3,4 & & & bark of Acer platanoides, Populus tremula \\
\hline Lecania fuscella (Schaer.) A. Massal. & 3,5 & $\begin{array}{l}7,9,11,14 \\
15\end{array}$ & $\begin{array}{l}18,21,26 \\
27\end{array}$ & $\begin{array}{l}\text { bark of deciduous trees, branches of Betula } \\
\text { sp. }\end{array}$ \\
\hline Lecania koerberiana J. Lahm & & 9,14 & & bark of old Betula sp., Salix sp. \\
\hline $\begin{array}{l}\text { Lecania naegelii (Hepp) Diederich \& } \\
\quad \text { van den Boom }\end{array}$ & & & $21,24,27$ & $\begin{array}{l}\text { bark of Populus tremula, Prunus padus L., } \\
\text { Salix sp., Tilia cordata }\end{array}$ \\
\hline Lecanora albellula (Nyl.) Th. Fr. & & $7-10$ & 24 & $\begin{array}{l}\text { bark of old Betula sp., old Larix sibirica, } \\
\text { old Pinus sylvestris }\end{array}$ \\
\hline Lecanora allophana Nyl. & 4,5 & & & bark of Quercus robur, Tilia cordata \\
\hline Lecanora carpinea (L.) Vain. & 5 & 11,13 & & $\begin{array}{l}\text { bark of Acer platanoides, Populus tremula, } \\
\text { Tilia cordata }\end{array}$ \\
\hline Lecanora chlarotera $\mathrm{Nyl}$. & & 14 & & bark of Populus tremula \\
\hline $\begin{array}{l}\text { Lecanora circumborealis Brodo \& } \\
\text { Vitik. }\end{array}$ & 3,4 & & & bark of Quercus robur \\
\hline $\begin{array}{l}\text { Lecanora leptyrodes (Nyl.) G. B. F. } \\
\text { Nilsson }\end{array}$ & 3 & & & bark of Acer platanoides \\
\hline Lecanora populicola (DC.) Duby & & 13 & 22 & bark of Acer tataricum L., Populus sp. \\
\hline Lecanora pulicaris (Pers.) Ach. & 5 & 12,14 & 25 & bark of old Betula sp., Tilia cordata \\
\hline Lecanora saligna (Schrad.) Zahlbr. & & & 25 & bark of old Betula sp. \\
\hline Lecanora symmicta (Ach.) Ach. & $1,3-5$ & $\begin{array}{l}9, \\
11-15\end{array}$ & $\begin{array}{l}17-19,22 \\
25,27\end{array}$ & $\begin{array}{l}\text { bark and branches of deciduous and co- } \\
\text { niferous trees }\end{array}$ \\
\hline $\begin{array}{l}\text { Lecidea erythrophaea Flörke ex Som- } \\
\text { merf. }\end{array}$ & & 8 & & rotted wood \\
\hline $\begin{array}{l}\text { Lecidella elaeochroma (Ach.) M. } \\
\text { Choisy f. soralifera (Erichsen) D. } \\
\text { Hawksw. }\end{array}$ & & 7 & & bark of Quercus robur; TLC: arthothelin \\
\hline $\begin{array}{l}\text { Lecidella flavosorediata (Vězda) Hertel } \\
\text { \& Leuckert }\end{array}$ & & & 17,27 & $\begin{array}{l}\text { bark of Betula sp., old Tilia cordata; TLC: } \\
\text { arthothelin, granulosin }\end{array}$ \\
\hline Lepraria elobata Tønsberg & $1,2,4$ & 14 & $\begin{array}{l}18,19 \\
23-26\end{array}$ & $\begin{array}{l}\text { bark of old Betula sp., old Quercus robur, } \\
\text { Tilia cordata, rotted wood }\end{array}$ \\
\hline
\end{tabular}


Table 1. (continued)

\begin{tabular}{lll}
\hline Taxon & \multicolumn{2}{l}{ Study plots within the museum-reserves Substrata and notes } \\
\cline { 2 - 3 } & Abramtsevo & A. S. Pushkin Ostafyevo
\end{tabular}

Lepraria finkii (B. de Lesd.) R. C. Harris

Lepraria incana (L.) Ach.

+ Leptorhaphis epidermidis (Ach.) 1 Th. Fr.

\# Lichenochora obscuroides (Linds.) Triebel \& Rambold (Fig. 2)

Melanelixia glabratula (Lamy) Sandler 2, 4 \& Arup

* Melanelixia subargentifera (Nyl.) O. Blanco et al.

Melanelixia subaurifera (Nyl.) O. 4 Blanco et al.

Melanohalea exasperata (De Not.) O. 1 Blanco et al.

Melanohalea exasperatula (Nyl.) O. 1 Blanco et al.

Melanohalea olivacea (L.) O. Blanco 1, 5 et al.

Micarea nitschkeana (J. Lahm ex Rabenh.) Harm.

+ Mycomicrothelia confusa D. Hawk- 2 sw.

+ Mycomicrothelia wallrothii (Hepp) D. Hawksw.

Myriolecis hagenii (Ach.) Śliwa et al.

Myriolecis persimilis (Th. Fr.) Śliwa 5 et al.

Myriolecis sambuci (Pers.) Clem.

Parmelia sulcata Taylor

*!! Parmelina tiliacea (Hoffm.) Hale

Parmeliopsis ambigua (Wulfen) Nyl. 1,4

Phaeophyscia nigricans (Flörke) Moberg

Phaeophyscia orbicularis (Neck.) 4, 5 Moberg: var orbicularis

var. hueiana (Harm.) Clauzade \& Cl. Roux

Phlyctis argena (Spreng.) Flot.

Physcia adscendens H. Olivier

Physcia aipolia (Ehrh. ex Humb.) 1, 4 Fürnr.
11

6,7 ,

$9-16$

6

18, 19, 24, bark of old Betula sp., Pinus sylvestris, old 27 Tilia cordata, old Ulmus sp.

18, 20, 24 bark of old Betula sp., old Quercus robur, old Tilia cordata; TLC: divaricatic acid, zeorin

18, 25 bark of Betula sp.

23 thallus of Phaeophyscia orbicularis growing on bark of old Acer platanoides; det. A. Tsurykau

bark of old Quercus robur, Tilia cordata

17, 18, 20, bark of old Acer platanoides, Malus sp., 23 Tilia cordata

bark of Betula sp.

bark of old Quercus robur

$6,7,11,15 \quad 17-20 \quad$ bark and branches of deciduous trees, bark of Picea abies, treated wood

bark of Betula sp., branch of deciduous trees

25 bark of old Pinus sylvestris

18,20 , bark of Tilia cordata

23-27

27 bark of Betula sp., Populus tremula

17, 22 bark of Acer platanoides, Acer tataricum, Fraxinus sp., old Salix sp., deciduous tree, treated wood

bark of Tilia cordata

bark of Alnus sp.

17-25, 27 bark and branches of deciduous trees and coniferous trees

18, 20 bark of old Betula sp., old Quercus robur, Tilia cordata

14 bark of Betula sp., old Quercus robur

9, 13, $14 \quad 17,18,20$, bark of deciduous trees, rotted wood $22,23,27$

7, 9-16 17-20,22, bark and branches of deciduous trees and 23, 25-27 coniferous trees, rotted and treated wood

27 bark of Populus tremula

18, 20, 24 bark of old Acer platanoides, old Betula sp., Tilia cordata

17-27 bark and branches of deciduous trees and coniferous trees, treated wood

$9-16$

7, 9, 10,

12-16
$17-19$, bark and branches of deciduous trees, bark 21-24, 27 of Picea abies, treated wood 
Table 1. (continued)

\begin{tabular}{|c|c|c|c|c|}
\hline \multirow[t]{2}{*}{ Taxon } & \multicolumn{3}{|c|}{ Study plots within the museum-reserves } & \multirow[t]{2}{*}{ Substrata and notes } \\
\hline & Abramtsevo & A. S. Pushkin & Ostafyevo & \\
\hline Physcia caesia (Hoffm.) Fürnr. & & 13 & & bark of old Populus sp. \\
\hline Physcia dubia (Hoffm.) Lettau & & $\begin{array}{l}6,7,10-12 \\
16\end{array}$ & $17-23,27$ & $\begin{array}{l}\text { bark of Betula sp., old Larix sibirica, Picea } \\
\text { abies, old Pinus sylvestris, Salix sp., Tilia } \\
\text { cordata }\end{array}$ \\
\hline Physcia stellaris (L.) Nyl. & 1 & 7,16 & $\begin{array}{l}17,18,22 \\
25\end{array}$ & $\begin{array}{l}\text { bark of Acer platanoides, Tilia cordata, } \\
\text { branches of Betula sp., Pinus sylvestris, } \\
\text { Quercus robur, Tilia cordata, deciduous } \\
\text { trees, treated wood }\end{array}$ \\
\hline Physcia tenella (Scop.) DC. & 4 & $6,11,12$ & $\begin{array}{l}18,19,22 \\
24\end{array}$ & $\begin{array}{l}\text { bark of Betula sp., old Pinus sylvestris, Popu- } \\
\text { lus tremula, old Quercus robur, old Salix sp., } \\
\text { Tilia cordata, treated wood }\end{array}$ \\
\hline Physcia tribacia (Ach.) Nyl. & & $6,10,12,13$ & 22,25 & $\begin{array}{l}\text { bark of Betula sp., old Larix sibirica, old } \\
\text { Quercus robur, old Tilia cordata, branch of } \\
\text { Pinus sylvestris }\end{array}$ \\
\hline Physconia detersa (Nyl.) Poelt & & $7,9,11,15$ & $\begin{array}{l}17-20,22 \\
24,27\end{array}$ & $\begin{array}{l}\text { bark of deciduous trees, bark of Pinus sylves- } \\
\text { tris coniferous trees, treated wood }\end{array}$ \\
\hline $\begin{array}{l}\text { Physconia distorta (With.) J. R. Laun- } \\
\text { don }\end{array}$ & 1,4 & & $17,18,23$ & $\begin{array}{l}\text { bark of Populus tremula, Quercus robur, old } \\
\text { Tilia cordata, Ulmus sp. }\end{array}$ \\
\hline Physconia enteroxantha (Nyl.) Poelt & 1,2 & $6,7,9,10,15$ & $17-27$ & bark and branches of deciduous trees \\
\hline Physconia cf. grisea (Lam.) Poelt & & 12 & & bark of Thuja occidentalis $\mathrm{L}$. \\
\hline $\begin{array}{l}\text { *Physconia perisidiosa (Erichsen) } \\
\text { Moberg }\end{array}$ & 1,2 & & 17 & bark of Betula sp., Tilia cordata \\
\hline $\begin{array}{l}\text { Polycauliona candelaria (L.) Frödén } \\
\text { et al. }\end{array}$ & & 7 & & bark of old Larix sibirica \\
\hline $\begin{array}{l}\text { Polycauliona polycarpa (Hoffm.) } \\
\text { Frödén et al. }\end{array}$ & & 6,7 & 17,20 & $\begin{array}{l}\text { bark of old Larix sibirica, Salix sp., old Pinus } \\
\text { sylvestris, branches of Betula sp. }\end{array}$ \\
\hline Pycnora praestabilis (Nyl.) Hafellner & & & 24 & bark of old Pinus sylvestris \\
\hline Pycnora sorophora (Vain.) Hafellner & & 8 & & bark of old Pinus sylvestris \\
\hline Ramalina europaea Gasparyan et al. & 2 & & $18,19,22$ & bark of old Tilia cordata \\
\hline !! Ramalina farinacea (L.) Ach. & 1,2 & & & bark of Tilia cordata \\
\hline Rinodina exigua (Ach.) Gray & 1 & & & branch of Quercus robur \\
\hline Rinodina pyrina (Ach.) Arnold & & 13 & $17,18,27$ & $\begin{array}{l}\text { bark of Acer platanoides, old Tilia cordata, } \\
\text { branches of Betula sp., Tilia cordata }\end{array}$ \\
\hline $\begin{array}{l}\text { Scoliciosporum sarothamni (Vain.) } \\
\text { Vězda }\end{array}$ & 2 & 7,11 & 17,18 & $\begin{array}{l}\text { bark of Salix sp., Sorbus aucuparia L., } \\
\text { Tilia cordata, branches of Betula sp., Tilia } \\
\text { cordata; TLC: gyrophoric acid }\end{array}$ \\
\hline !" Usnea dasopoga (Ach.) Nyl. & 1 & & & bark of Tilia cordata \\
\hline $\begin{array}{l}\text { ! Usnea hirta (L.) Weber ex F. H. } \\
\text { Wigg. }\end{array}$ & & & 18 & bark of old Tilia cordata \\
\hline !! Usnea subfloridana Stirt. & 4 & & & bark of Betula sp. \\
\hline Violella fucata (Stirt.) T. Sprib. & 4 & & & bark of Betula sp., old Quercus robur \\
\hline $\begin{array}{l}\text { Vulpicida pinastri (Scop.) J.-E. Matts- } \\
\text { son \& M. J. Lai }\end{array}$ & 1,4 & 14,16 & & bark of Betula sp. \\
\hline $\begin{array}{l}\text { Xanthomendoza fallax (Hepp) Søcht- } \\
\text { ing et al. }\end{array}$ & & & 20 & bark of Ulmus sp. \\
\hline Xanthoria parietina (L.) Th. Fr. & 1,4 & $\begin{array}{l}5,7 \\
9-16\end{array}$ & $17-27$ & $\begin{array}{l}\text { bark and branches of deciduous trees and } \\
\text { coniferous trees, treated wood }\end{array}$ \\
\hline
\end{tabular}


Table 2. The specificity of the lichen biota in the surveyed parks

\begin{tabular}{lccc}
\hline The park & $\begin{array}{l}\text { Number of species found only in } \\
\text { one of the surveyed parks }\end{array}$ & $\begin{array}{l}\text { Total number of species found } \\
\text { in all surveyed parks }\end{array}$ & The specificity \\
\hline Museum-reserve Abramtsevo & 15 & 103 & 14.6 \\
Museum-reserve of A. S. Pushkin & 14 & 103 & 13.6 \\
Museum-estate Ostafyevo & 19 & 103 & 18.4 \\
\hline
\end{tabular}

Table 3. Similarity matrix of the lichen biota in the surveyed parks indicating Sørensen Index values (in bold) and the number of joint species for pairs of parks

\begin{tabular}{lccc}
\hline The park & $\begin{array}{c}\text { Museum-reserve } \\
\text { Abramtsevo }\end{array}$ & $\begin{array}{c}\text { Museum-reserve of } \\
\text { A.S. Pushkin }\end{array}$ & Museum-estate Ostafyevo \\
\hline Museum-reserve Abramtsevo & - & $\mathbf{0 . 5 1}$ & $\mathbf{0 . 5 6}$ \\
Museum-reserve of A. S. Pushkin & 29 & - & $\mathbf{0 . 6 1}$ \\
Museum-estate Ostafyevo & 35 & 39 & - \\
\hline
\end{tabular}

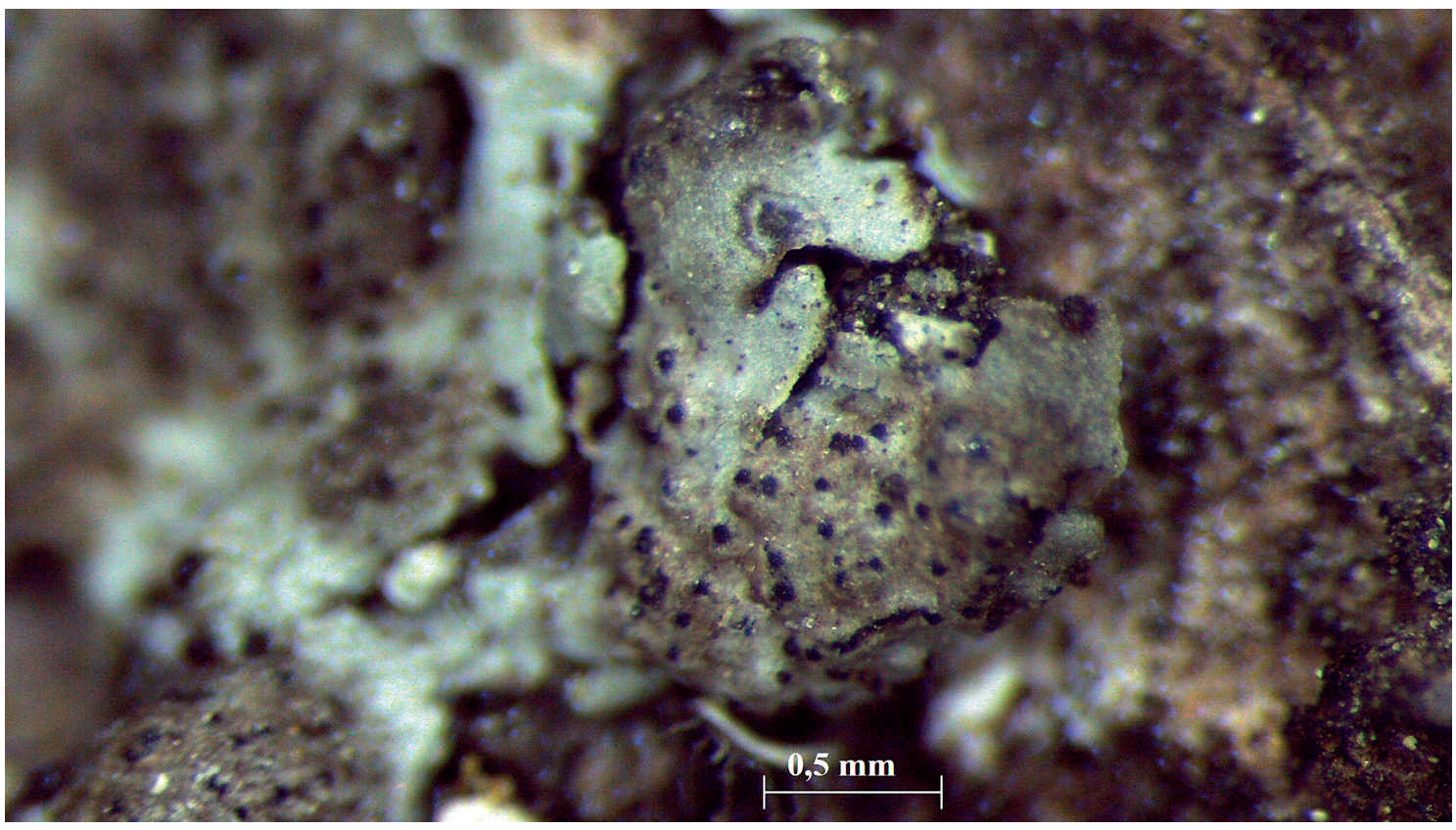

Fig. 2. Lichenochora obscuroides (Linds.) Triebel \& Rambold: caps of perithecia on the lobes of Phaeophyscia orbicularis.

trees, as well as a higher anthropogenic impact, compared to the park of the MR Abramtsevo.

Menhinik Index and Shannon Index of Diversity values showed that the relative indicators of the species richness and diversity of the lichen biota in the park of the MR Abramtsevo were higher than in the other parks (Table 4). These indices probably reflect the fact that the Abramtsevo park is located in a rural area with moderate degree of anthropogenic impact (Kolosova \& Churilova, 2004), while the parks of the MR of A. S Pushkin and the ME Ostafyevo are located within urban areas with a significant anthropogenic impact.

We plan to use the Menhinik Index and Shannon Index of Diversity as relative indicators of species 
Table 4. Menhinik Index and Shannon Index of Diversity values of the lichen biota in the surveyed parks

\begin{tabular}{lcc}
\hline The park & Menhinik Index & Shannon Index of Diversity \\
\hline Museum-reserve Abramtsevo & 4.57 & 1.60 \\
Museum-reserve of A. S. Pushkin & 2.96 & 1.41 \\
Museum-estate Ostafyevo & 2.90 & 1.53 \\
\hline
\end{tabular}

richness and diversity in comparative analysis in further studies of the park lichen biota of the museum-reserves in the Moscow Region.

\section{Suggestions to include new species into the Red Data Book of Moscow}

Since 2012, the territory of the city of Moscow has greatly increased due to the accession of the Novomoskovsky and Troitsky administrative districts. As a result, the lists of species included in the Red Data Book of Moscow (2011) are largely outdated.

Within this study, Chaenotheca chrysocephala, Melanelixia subargentifera, Parmelina tiliacea, Physconia perisidiosa and Ramalina europaea were found in the park of the ME Ostafyevo Russian Parnassus and should be recommended for the next edition of the Red Data Book of Moscow.

Chaenotheca chrysocephala, like most of the calicioid lichens and fungi, is highly sensitive to environmental alterations of anthropogenic nature (Tibell, 1999). Previously, the species was singly noted in the early 20th century on the territory now occupied by Moscow (Elenkin, 1906-1911). C. chrysocephala is scattered in the Moscow Oblast (Golubkova, 1966; Biazrov, 1993; Pchelkin, 2005; Notov, 2010; etc.).

Melanelixia subargentifera and Parmelina tiliacea are indicators of mature broad-leaved forests and old parks in the Northwest of European Russia (Himelbrant \& Kuznetsova, 2009). These species retain indicator properties in Central Russia and are considered as indicators of biologically valuable broadleaved forest and park landscapes in the subzone of mixed coniferousbroadleaved forests (Muchnik, 2015a). Melanelixia subargentifera was previously recorded on the territory of Moscow within its new borders with no exact locality and date of discovery (Biazrov, 2012). To date, in the Moscow Oblast it has been revealed within specially protected natural areas Prioksko-Terrasny Nature Biosphere Reserve (Pchelkin, 2005) and Zavidovo National Park (Notov, 2010). The few findings of Parmelina tiliacea in Moscow are from the last century (Elenkin, 1906-1911; Biazrov, 1996, Pchelkin, 1998). In the Moscow Oblast, the species is rare and listed in the Red Data Book of the Moscow Oblast (2018) with category 2 Threatened species.

Physconia perisidiosa is also considered as indicator of biologically valuable forest and park landscapes in the subzone of mixed coniferousbroadleaved forests of Central Russia (Muchnik, 2015a). The species is extremely rare in the region; it has been singly recorded in Moscow (Muchnik, 2016) and the Moscow Oblast (Muchnik et al., 2018).

Ramalina europaea has been described very recently (Gasparyan et al., 2017). To update the data on the distribution of Ramalina species in the Moscow Region, it is necessary to revise all available material for this genus in MW and LE herbaria. All species of the genus known in Moscow Region are sensitive to anthropogenic impact and confined to areas of well-preserved forest and park communities, and therefore listed in the Red Data Book of Moscow (2011) and Red Data Book of the Moscow Oblast (2018).

All the mentioned species need protection on the territory of the city of Moscow due to their rare occurrence and special requirements for the ecological niche, i. e. forest or park communities with the presence of old broadleaved trees.

\section{ACKNOWLEDGEMENTS}

The authors are grateful to the administrations of the museum-reserve Abramtsevo, the museum-reserve of A. S. Pushkin and the museumestate Ostafyevo - Russian Parnassus for their 
assistance in organizing research, as well as to colleagues G. P. Urbanavichus (Institute of North Industrial Ecology Problems, Kola Science Centre RAS), I. N. Urbanavichene, L. A. Konoreva (Komarov Botanical Institute RAS), A. G. Paukov (Yeltsin Ural Federal University), A. Tsurykau (Francisk Skorina Gomel State University) and M. Kukwa (Gdansk University) for helping to identify and confirm some difficult taxa. Sincere thanks to Susan Will-Wolf (University of Wisconsin, USA) and John Wolf for linguistic assistance. Thanks to anonymous reviewers and the associate editor for the constructive comments and suggestions on the manuscript.

\section{REFERENCES}

Biazrov, L. G. 1993. Some results of the use of lichenocenological research in monitoring the state of the environment in the Moscow Region (In Russian). Bioindication in cities and suburban areas: 55-72.

Biazrov, L. G. 1996. Species diversity lichens of Moscow (In Russian, English abstract). Bulletin of Moscow Society of Naturalists. Biological series 3: 68-77.

Biazrov, L. G. 2009. Epiphytic lichens of Moscow city: recent changes of species diversity (In Russian, English abstract). Moscow. 146 pp.

Biazrov, L. G. 2012. The species composition of the lichen biota on the territory of the Greater Moscow (In Russian). Version 1, 2012. http://www.sevin. ru/laboratories/biazrov_big_msk_2012.html (26 May 2020).

Cherepenina, D. A. \& Muchnik, E. E. 2019. On the lichen biota of the park of the museum-estate "Ostafyevo" - "Russian Parnas" (Moscow) (In Russian, English abstract). Diversity of Plant World 3(3): 45-55. https://doi.org/10.22281/26869713-2019-3-45-55

Elenkin, A. A. 1906-1911. Lichen flora of Central Russia: edition of the Natural History Museum of countess U. L. Sheremetyeva in the village Mikhailovsky of the Moscow province (In Russian). Parts 1-4. Yuriev. 682 pp.

Gagarina, L. V., Chesnokov, S. V., Konoreva, L. A., Stepanchikova, I. S., Yatsyna, A. P., Kataeva, O. A., Notov, A. A. \& Zhurbenko, M. P. 2020. Lichens of the former manors in the Smolensk Region of Russia. Novosti sistematiki nizshikh rastenii 54(1): 93-116. https://doi.org/10.31111/ nsnr/2020.54.1.93

Gasparyan, A., Sipman, H. J. M. \& Lücking, R. 2017. Ramalina europaea and $R$. labiosorediata, two new species of the $R$. pollinaria group (Ascomycota: Ramalinaceae), and new typifications for Lichen pollinarius and L. squarrosus. The Lichenologist 49(4): 301-319. https://doi.org/10.1017/ S0024282917000226
Golubkova, N. S. 1966. The Handbook of lichens of the middle zone of the European part of the USSR (In Russian). Moscow-Leningrad. $256 \mathrm{pp}$.

Gudovicheva, A. V. 2001. Materials for lichen flora of the museum-reserve "Yasnaya Polyana" (In Russian). The Biological Diversity of the Tula Region at the Turn of the Century: 1: 3-6.

Notov, A. A. 2010. National park "Zavidovo": Vascular plants, Bryophytes, Lichens (In Russian). Moscow. $432 \mathrm{pp}$.

Himelbrant, D. E. \& Kuznetsova, E. S. 2009. Lichens. Identification and investigation of biologically valuable forests in the North-West of the European part of Russia (In Russian). Guidelines for the Identification of Species Used in Investigation at the Level of Stratum 2: 93-138.

Kolosova, N. N. \& Churilova, E. A. 2004. Atlas. Moscow Region (In Russian). Moscow. 48 pp.

Leont'ev, D. V. 2008. Floristic analysis in mycology (In Russian). Kharkiv. 110 pp.

Liira, J., Suija, A. \& Jüriado, I. 2020. Habitat and host specificity of epiphytic lichens in a rural landscape: cultural heritage habitats as refugia. Biodiversity and Conservation 29(7): 2141-2160. https://doi.org/10.1007/s10531-020-01955-1

Likhacheva, O. V. 2010. Lichens of manor parks in the Pskov Region. Synopsis of thesis for the degree of candidate of biological sciences (In Russian). Pskov. 23 pp.

Lindblom, L., Blom, H. H. \& Timdal, E. 2019. The genus Xanthomendoza in Norway. Graphis Scripta 31(7): 54-75.

Lücking, R., Hodkinson, B. P. \& Leavitt, S. D. 2016. The 2016 classification of lichenized fungi in the Ascomycota and Basidiomycota. Approaching one thousand genera. The Bryologist 119: 361-416. https:/ / doi.org/10.1639/0007-2745-119.4.361

Magurran, A. E. 2004. Measuring biological diversity. Oxford, UK. 256 pp.

Malysheva, N. V. 1999. Lichens of the cities of the Ivanovo Region (In Russian). Botanical Journal 84(2): 59-67.

Maslovsky, O. M. 1990. The principles of comparative analysis of bryoflora (In Russian). Botany: Research 30: 156-160.

Muchnik, E. E. 2014. The first data about corticolous lichens of the park of "Spasskoye-Lutovinovo" museum-reserve (Orel Region, Central Russia) (In Russian, English abstract). Scientific notes of Orel State University. Series: Natural, Technical and Medical Sciences 6(62): 71-74.

Muchnik, E. E. 2015. The role of the museum-reserves of the Central Russia in the conservation of the diversity of regional lichen biota (In Russian). Museum-Reserve: Ecology and Culture. Materials of the Sixth International Scientific and Practical Conference. Pp. 160-164.

Muchnik, E. E. 2015a. Lichens as indicators of forest ecosystems in the Center of European Russia (In Russian, English abstract). Forest 
Engineering Journal 5(3): 65-76. https://doi. org/ 10.12737/14154

Muchnik, E. E. 2016. Additions to lichen biota of Moscow Region. (In Russian, English abstract). Proceedings of Petrozavodsk State University. General Biology 8 (161): 52-57.

Muchnik, E. E., \& Cherepenina, D. A. 2018. To the study of the lichen biota of the parks of A.S. Pushkin Museum-Reserve (Moscow Region) (In Russian, English abstract). Samara Luka: Problems of Regional and Global Ecology 27(4): 232-239. DOI: 10.24411/2073-1035-2018-10119.

Muchnik, E. E., Cherepenina, D. A. \& Polynova, O. E. 2018. Lichen biota of the park of the museumreserve "Abramtsevo" (Moscow Region) (In Russian, English abstract). RUDN Journal of Ecology and Life Safety 26(2): 175-184. https:/ / doi. org/10.22363/2313-2310-2018-26-2-175-184

Nordin, A., Moberg, R., Tønsberg, T., Vitikainen, O., Dalsätt, Å., Myrdal, M., Snitting, D. \& Ekman, S. 2011. Santesson's Checklist of Fennoscandian Lichen-forming and Lichenicolous Fungi. Version 29 April 2011. http://130.238.83.220/santesson/home.php (11 February 2020)

Orange, A., James, P. W. \& White, F. J. 2001. Microchemical methods for the identification of lichens. British Lichen Society. London. 101 pp.
Pchelkin, A. V. 1998. Distribution of lichens in Moscow (In Russian). Moscow. 21 pp.

Pchelkin, A. V. 2005. Comparison of the lichen flora of Moscow and the Prioksko-Terrasny Reserve (In Russian). Ecosystems of the Prioksko-Terrasny Nature Biosphere Reserve: 95-104.

Pchelkin, A.V. \& Pchelkina, T. A. 2015. Lichenological researches in the museum-reserve "Kolomenskoye" (In Russian). Modern Mycology in Russia: Materials of the III International Mycological Forum 4: 345-346.

Red Data Book of Moscow (In Russian). 2011. Moscow. 928 pp.

Red Data Book of the Moscow Oblast (In Russian). 2018. Moscow Oblast. 810 pp.

Sørensen, T. 1948. A method of establishing groups of equal amplitude in plant sociology based on similarity of species content. Det Kongelige Danske Videnskabernes Selskab Biologiske Skrifter 5 (4): 1-34.

Tibell, L. 1999. Calicioid lichens and fungi. Nordic Lichen Flora 1: 20-94. https://doi.org/ 10.1111/j.1756-1051.2000.tb00759.x

Tsurykau, A. \& Korchikov, E. S. 2017. Lichenicolous fungi from the Samara Region, southern part of European Russia. Folia Cryptogamica Estonica 54: 1-8. https: / / doi.org/ 10.12697/fce.2017.54.01 
Appendix 1. Description of studied localities in the surveyed parks

No. Geographical coordinates, habitat

Date

Museum-reserve Abramtsevo (area 50 ha)

$156^{\circ} 14.060^{\prime} \mathrm{N}, 37^{\circ} 58.010^{\prime} \mathrm{E}$, Betula sp., Picea abies, Quercus robur, Tilia cordata around the Upper pond

22.06.2016

$256^{\circ} 14.103^{\prime} \mathrm{N}, 37^{\circ} 58.109^{\prime} \mathrm{E}$, alleys of Tilia cordata, with old Picea abies, Quercus robur, Sorbus aucuparia, behind the

22.06 .2016 manor house, slope to the river Vorya

$356^{\circ} 14.188^{\prime} \mathrm{N}, 37^{\circ} 58.119^{\prime} \mathrm{E}$, Acer platanoides, Quercus robur along the bank of the river Vorya

22.06.2016

$4 \quad 56^{\circ} 14.201^{\prime} \mathrm{N}, 37^{\circ} 58.343^{\prime} \mathrm{E}$, Betula sp., old Pinus sylvestris, Populus tremula, Quercus robur, Tilia cordata along the

10.08 .2016 bank of the river Vorya

$5 \quad 56^{\circ} 14.122^{\prime} \mathrm{N}, 37^{\circ} 58.238^{\prime} \mathrm{E}$, Betula sp., Pinus sylvestris, Populus tremula, Tilia cordata around the Lower pond, near

10.08 .2016 the automobile road

Museum-reserve of A. S. Pushkin (area 32 ha)

Estate Vyazemy

$6 \quad 55^{\circ} 37.671^{\prime} \mathrm{N}, 36^{\circ} 59.473^{\prime} \mathrm{E}$, old Larix sibirica, Tilia cordata near the entrance to the park near the church

23.08.2017

$7 \quad 55^{\circ} 37.692^{\prime}$ N, 3659.400’E, Acer platanoides, old Betula sp., Fraxinus sp., old Larix sibirica, old Populus sp., Quercus robur, Salix sp., Tilia cordata near the dam on the Vyazemka river

23.08 .2017

30.08 .2017

$8 \quad 55^{\circ} 37.744^{\prime} \mathrm{N}, 36^{\circ} 59.583^{\prime} \mathrm{E}$, old Pinus sylvestris east of the dam on the Vyazemka river, opposite the automobile

23.08.2017 road.

$9 \quad 55^{\circ} 37.766^{\prime} \mathrm{N}, 36^{\circ} 59.575^{\prime} \mathrm{E}$, Betula sp., Larix sibirica, Quercus robur, Rhamnus sp., Salix sp., old Tilia cordata, Ulmus sp. near the automobile road in the area of the Godunovsky ravine

$10 \quad 55^{\circ} 37.664^{\prime}$ N, 36 59.426'E, Acer platanoides, old Betula sp., old Larix sibirica, Picea abies, Syringa sp., Tilia cordata around the Church of the Transfiguration (the Life-Giving Trinity)

$1155^{\circ} 37.663^{\prime} \mathrm{N}, 36^{\circ} 59.511^{\prime} \mathrm{E}$, regular park with Alnus sp., Larix sibirica, old Quercus robur, Tilia cordata

09.09.2017

$1255^{\circ} 37.646^{\prime}$ N, 36 59.407'E, Frangula alnus Mill., old Larix sibirica, old Quercus robur, old Salix sp., Thuja occidentalis, Tilia cordata around the stable yard

$1355^{\circ} 37.652^{\prime} \mathrm{N}, 36^{\circ} 59.459^{\prime} \mathrm{E}$, large field with Acer platanoides, Betula sp., Malus sp., Populus sp., Rhamnus sp., Salix sp., Sorbus aucuparia, old Tilia cordata

30.08.2017

30.08 .2017

09.09 .2017

09.09 .2017

Estate Zakharovo

$14 \quad 55^{\circ} 38.806^{\prime} \mathrm{N}, 36^{\circ} 58.260^{\prime} \mathrm{E}$, park with Acer negundo L., old Betula sp., Populus tremula, Tilia cordata, Ulmus sp.

15.09 .2017

$1555^{\circ} 38.804^{\prime} \mathrm{N}, 36^{\circ} 58.224^{\prime} \mathrm{E}$, fruit grove of Malus sp., old Pyrus sp., with old Betula sp., Rhamnus sp.

07.10 .2017

$16 \quad 55^{\circ} 38.682^{\prime} \mathrm{N}, 36^{\circ} 58.213^{\prime} \mathrm{E}$, old Betula sp., Salix sp., Tilia cordata near the manor pond

07.10 .2017

Museum-estate Ostafyevo - Russian Parnassus (area 40 ha)

$17 \quad 55^{\circ} 29.703^{\prime} \mathrm{N}, 37^{\circ} 30.166^{\prime} \mathrm{E}$, Acer platanoides, Betula sp., Salix sp., old Tilia cordata in front of the main house, near the Big pond

$1855^{\circ} 29.816^{\prime} \mathrm{N}, 37^{\circ} 30.109^{\prime} \mathrm{E}$, behind the main house, row of Tilia cordata «Russian Parnassus», with Betula sp., old Pinus sylvestris, old Quercus robur, Salix sp. near the Big pond

$1955^{\circ} 29.794^{\prime} \mathrm{N}, 37^{\circ} 29.923$ 'E, old Betula sp., Pinus sylvestris, old Tilia cordata, old Ulmus sp. to the left of the Field of Mars and behind it

$20 \quad 55^{\circ} 29.725^{\prime} \mathrm{N}, 37^{\circ} 30.055^{\prime}$ E Acer platanoides, Betula sp., Picea abies, old Pinus sylvestris, old Populus sp., old Quercus robur, Sorbus aucuparia, Syringa sp., Tilia cordata, Ulmus sp. in front of the main house

$21 \quad 55^{\circ} 29.708^{\prime} \mathrm{N}, 37^{\circ} 30.107^{\prime} \mathrm{E}$ floodplain of the Lobuchi river with Acer platanoides, Prunus padus, Salix sp.

$2255^{\circ} 29.715^{\prime} \mathrm{N}, 37^{\circ} 30.019^{\prime} \mathrm{E}$, Acer platanoides, Acer tataricum, Betula sp., Malus sp., Sorbus aucuparia, old Tilia cordata around the cabinet of medals

$2355^{\circ} 29.668^{\prime} \mathrm{N}, 37^{\circ} 30.143^{\prime} \mathrm{E}$ old Acer platanoides, old Betula sp., Malus sp., old Quercus robur, old Tilia cordata, Ulmus sp. near the building of the former cloth factory

$2455^{\circ} 29.892^{\prime} \mathrm{N}, 37^{\circ} 29.836^{\prime} \mathrm{E}$, coniferous grove of old Pinus sylvestris, with old Betula sp., Tilia cordata

$2555^{\circ} 29.996^{\prime} \mathrm{N}, 37^{\circ} 29.629^{\prime} \mathrm{E}$, Karamzin grove of old Betula sp., with old Pinus sylvestris, old Tilia cordata

$2655^{\circ} 29.902^{\prime} \mathrm{N}, 37^{\circ} 29.855^{\prime} \mathrm{E}$, Acer platanoides, old Betula sp., old Tilia cordata along the bank of the Big pond, Dorsky stream, behind the arbor «Temple of Apollo»

17.06.2018

19.06.2018

17.06 .2018

19.06.2018

19.06 .2018

23.06.2018

27.06 .2018

23.06 .2018

23.06.2018

23.06.2018

27.06.2018

29.06 .2018

29.06 .2018

29.06 .2018

$2755^{\circ} 29.947^{\prime}$ N, $37^{\circ} 29.939^{\prime}$ E, Acer platanoides, old Betula sp., Populus tremula, Salix sp., old Tilia cordata on the right bank of the Big pond

03.07.2018 